\title{
RELATIONSHIP BETWEEN SERUM TRANSFORMING GROWTH FACTOR B1 AND LIVER COLLAGEN CONTENT IN RATS TREATED WITH CARBON TETRACHLORIDE
}

\author{
Fernanda dos Santos OLIVEIRA ${ }^{\mathbf{1}, 2}$, Themis Reverbel da SILVEIRA ${ }^{1}$ and \\ Ursula MATTE1, 2
}

\begin{abstract}
Context - Transforming Growth Factor B1 (TGFß1) plays a fundamental role in fibrogenesis, although its importance as a biomarker of liver disease is still matter of debate. Objective - Quantify serum TGFß1 and its association to liver collagen content in rats exposed to Carbon Tetrachloride $\left(\mathrm{CCl}_{4}\right)$. Methods - Rats were submitted to a fibrosis model using $\mathrm{CCl}_{4}$ and sacrificed after 6, 10, 12 and 16 weeks of treatment. Serum levels of TGFß1 were measured by ELISA and collagen content was defined by morphometric analysis. Results - Serum levels of TGFß1 increased between 6 and 10 weeks, whereas collagen density increased between 12 and 16 weeks. A negative correlation was observed between liver collagen deposition and serum levels of TGFß1 $(\mathrm{r}=-0.48 ; P<0.05)$. Conclusion - Serum levels of TGFß1 were inversely proportional to collagen intensity in cirrhotic livers of rats exposed to $\mathrm{CCl}_{4}$, thus suggesting a limited use as biomarker in advanced liver disease.
\end{abstract}

HEADINGS - Liver cirrhosis, experimental. Transforming growth factor beta 1. Collagen. Carbon Tetrachloride. Rats.

\section{INTRODUCTION}

Liver fibrosis may be triggered by factors such as viruses, extra hepatic billiary obstruction, toxins and metabolic syndrome. All chronic liver diseases have in common the gradual progressive substitution of the functioning hepatic parenchyma by fibrotic tissue, which can evolve to cirrhosis ${ }^{(6)}$. Currently, the mechanisms of fibrogenesis are under extensive study, due to the increase in obesity and the high prevalence of hepatitis $\mathrm{C}$ virus ${ }^{(6)}$. Although the histopathologic study of the liver has been considered the "gold standard" for grading and staging fibrosis, liver biopsy has disadvantages such as sampling error, inter-observer variability, potential complications and its accuracy nowadays is questioned. There has been increasing interest in non-invasive assessment of liver fibrosis in place of liver biopsy using surrogate markers measurable in the peripheral blood or by using instrumental devices ${ }^{(11,14)}$. The serological noninvasive markers of liver fibrosis can be classified into indirect (or surrogate) and direct (or biomarkers). Among direct tests hyaluronic acid, procollagens, matrix metalloproteins and cytokines such as TGFß1 and adiponectin are used ${ }^{(6)}$.

Transforming Growth Factor B1 (TGFB1) is one of the main profibrotic cytokine involved in liver fibrosis, inducing differentiation of hepatic stellar cells (HSCs) into myofibroblasts ${ }^{(9)}$. The activation of HSC leads to increased production of collagen, proteoglycans, structural glycoproteins, and hyaluronic $\mathrm{acid}^{(7)}$. Therefore TGFß1 has been considered a target for treatment of fibrosis, as wells as a useful biomarker for staging liver disease $\mathrm{e}^{(1,10,4)}$.

In this study we aimed to evaluate serum levels of TGFB1 in rats submitted to experimental Carbon Tetrachloride $\left(\mathrm{CCl}_{4}\right)$ toxicity model and its correlation with collagen deposition in liver tissue.

\section{METHODS}

Male Wistar rats $(\mathrm{n}=25)$ were submitted to $\mathrm{CCl}_{4}$ administration as described by Goldani et al. ${ }^{(5)}$. Animals were sacrificed at weeks $6,10,12$ and 16 (n = 5 per time point). Before sacrifice in $\mathrm{CO}_{2}$ chambers, blood was collected and kept at $-80^{\circ} \mathrm{C}$ until analysis. Serum TGFß1 measurement was performed by ELI-

Conflict of interests: none.

Financial source: CNPq and FIPE/HCPA

${ }^{1}$ Laboratory of Experimental Gastroenterology and Hepatology, Experimental Research Center, Hospital de Clínicas de Porto Alegre; ${ }^{2}$ Gene Therapy Center, Experimental Research Center, Hospital de Clínicas de Porto Alegre, RS, Brasil.

Correspondence: Dr. Ursula Matte - Rua Ramiro Barcelos, 2350 - Porto Alegre, RS, Brazil. E-mail: umatte@hcpa.ufrgs.br 
SA (R\&D Systems, USA), according to the manufacturer's instructions. Basal levels were determined in five non-exposed animals. After sacrifice, liver was paraffin-embedded and Sirius red stained. Collagen density was defined as the mean values of collagen percentage in five liver images, quantified by the morphometric method, as described by de Oliveira et al. ${ }^{(3)}$. Image analysis was made with Image-Pro Plus version 4.1 software (Media Cybernetics, USA). Statistical analysis was performed with Microsoft Excell 2007 (Microsoft Corp, USA) and SPSS 15.0 (SPSS Inc, USA) Findings were expressed as mean \pm SD and compared using Student's test or analysis of variance followed by the Tukey post hoc test. Correlations were evaluated using Pearson's test.

\section{RESULTS}

Serum levels of TGFß1 increased around 6 times after 6 and 10 weeks of $\mathrm{CCl}_{4}$ exposure (Figure 1). Meanwhile, liver collagen deposition was still low with a gradual increase from week 6 to 10. However, a steady increase was observed between weeks 10 and 12, with the percentage of collagen reaching almost $50 \%$ at week 16 . During this same period
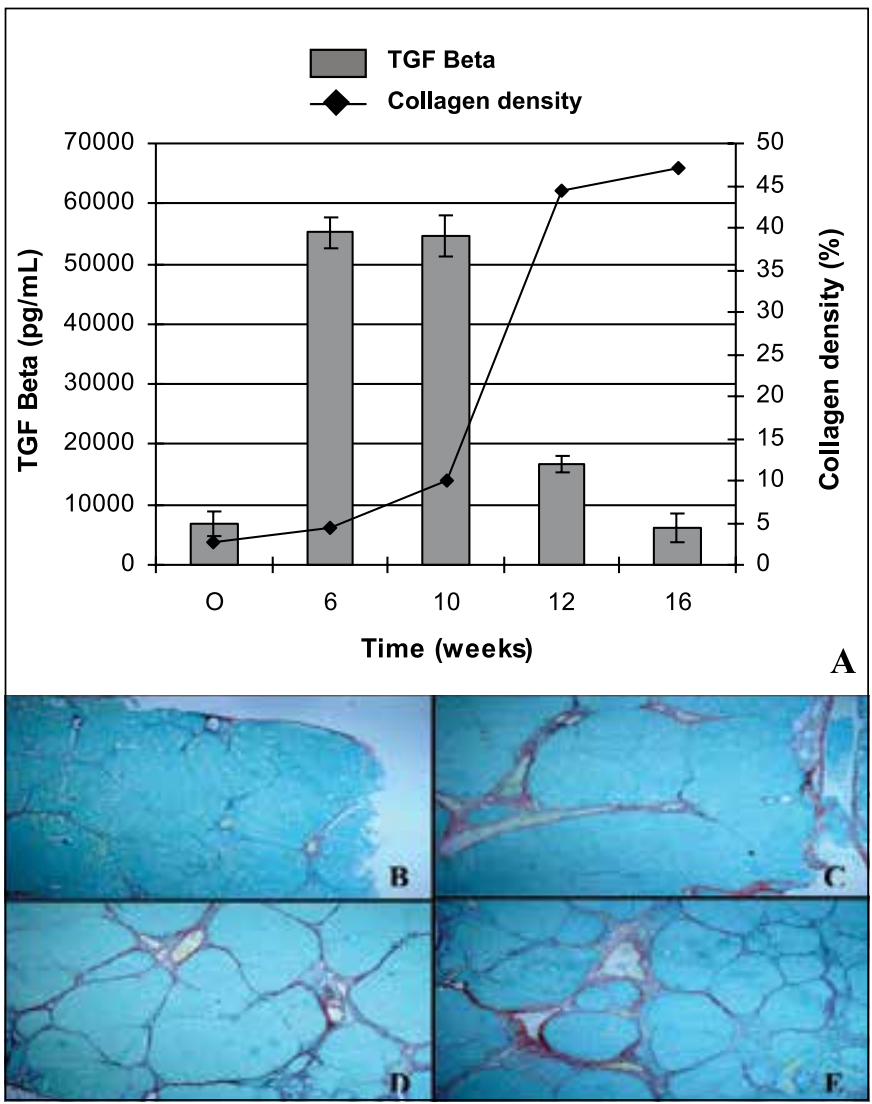

FIGURE 1. A) Mean levels of serum TGF $\beta 1(\mathrm{ng} / \mathrm{mL})$ and collagen density $(\%)$ at different times of Carbon Tetrachloride exposition. B-E) Liver tissue from Carbon Tetrachloride exposed rats stained with Syrius Red. B) 6 weeks, C) 10 weeks, D) 12 weeks, E) 16 weeks. $200 \mathrm{X}$ there was a significant reduction in TGFß1 serum levels that at week 16 were similar to those of control animals. A moderate negative correlation was observed $(-0.48 ; P<0.05)$ between liver collagen content and TGFß1 serum levels.

\section{DISCUSSION}

Chronic liver diseases represent a major public health problem, accounting for important morbidity and mortality worldwide. Despite their different etiologies, chronic liver diseases have in common the formation and accumulation of fibrosis leading to a progressive distortion of hepatic architecture. The management of these disorders depends, in many cases, on the amount and progression of liver fibrosis. Identifying the natural history of fibrosis deposition is important to evaluate the severity of liver damage and to establish the prognosis ${ }^{(12)}$.

In recent years, an increasing number of reliable non invasive methods became available to assess the development of liver fibrosis. Their utility is accepted in advanced fibrosis but an important limitation of these tests is the inability to detect mild stages of fibrosis. In humans, serum hyaluronic acid was the parameter that alone presented the best diagnostic accuracy in the assessment of hepatic fibrosis in chronic hepatitis $\mathrm{C}^{(13)}$ and serum levels of TGFB1 correlated with the rate of fibrosis progression in hepatitis $\mathrm{C}$ adult patients ${ }^{(2)}$. In children with biliary atresia serum TGFß1 was lower at the time of liver transplant compared with the time of diagnosis ${ }^{(15)}$.

Although TGFß1 is increased in $\mathrm{CCl}_{4}$-induced cirrhosis in rats, the kynetics of this cytokine in serum is not well known. Nakatsukasa et al. ${ }^{(11)}$ studied the tissue expression of TGFß1 in the liver of animals that received $\mathrm{CCl}_{4}$ for 12 weeks and observed fluctuations along the time but without a defined tendency ${ }^{(3)}$. In the present work we show a marked decrease in serum TGFB1 at end stage liver disease. At week 16, all animals in our study presented well established cirrhosis, with regenerative nodules and increased collagen density, which suggests that changes in vascular permeability may be occurring; similar to what has been observed in children with biliary atresia ${ }^{(15)}$. A similar study was conducted with serum laminin in the $\mathrm{CCl}_{4}$ fibrosis model. Although a correlation between increased laminin and the degree of fibrosis has been observed, only cirrhotic animals showed values statistically higher than controls ${ }^{(16)}$.

Taken together, these results suggest that biomarkers are useful for the diagnosis or the exclusion of cirrhosis in animal models but that caution must be taken in order to interpret these results and correlate them with histological findings.

\section{ACKNOWLEDGEMENTS}

The authors are thankful for Prof. Luise Meurer and Dr. Carlos Kieling, and Bárbara Grossmann for their help in data analysis. We also thank CNPq and FIPE/HCPA for financial support. 
Oliveira FS, Silveira TR, Matte U. Relação entre fator transformador de crescimento $\beta 1$ e conteúdo hepático de colágeno em ratos tratados com tetracloreto de carbono. Arq Gastroenterol. 2012,49(3):232-4.

RESUMO - Contexto - A citocina TGFß1 (Fator Transformador de Crescimento, TGFß1) desempenha um papel fundamental na fibrogênese, mas sua importância como biomarcador da doença hepática ainda tem sido debatida. Objetivo - Quantificar o TGFß1 sérico e estudar a sua associação com o conteúdo de colágeno no tecido hepático em ratos expostos ao Tetracloreto de Carbono $\left(\mathrm{CCl}_{4}\right)$. Métodos - Ratos foram submetidos ao modelo de fibrose por $\mathrm{CCl}_{4}$ e sacrificados após 6, 10,12 e 16 semanas de tratamento. Os níveis séricos de TGFß1 foram quantificados por ELISA e a densidade de colágeno foi definida por morfometria. Resultados - Os níveis séricos de TGFß1 aumentaram entre 6 e 10 semanas, enquanto a densidade de colágeno aumentou entre 12 e 16 semanas. Foi detectada uma correlação negativa entre a deposição hepática de colágeno e a concentração sérica de TGFß1 ( $\mathrm{r}=-0,48 ; P<0,05)$. Conclusão - O nível sérico de TGFß1 foi inversamente proporcional à intensidade do colágeno no fígado de ratos com cirrose por $\mathrm{CCl}_{4}$, o que indica que seu uso como biomarcador em estágios avançados da doença pode ter utilidade limitada.

DESCRITORES - Cirrose hepática experimental. Fator de Crescimento Transformador beta 1. Colágeno. Tetracloreto de Carbono. Ratos.

\section{REFERENCES}

1. Castera L. Invasive and non-invasive methods for the assessment of fibrosis and disease progression in chronic liver disease. Best Pract Res Clin Gastroenterol. 2011;25:291-303

2. Chávez E, Castro-Sánchez L, Shibayama M, Tsutsumi V, Moreno MG, Muriel P. Sulfasalazine prevents the increase in TGF-beta, COX-2, nuclear NFkappaB translocation and fibrosis in CCl4-induced liver cirrhosis in the rat. Hum Exp Toxicol. 2012 Mar 1.

3. de Oliveira F dos S, Kieling CO, dos Santos JL, de Leon Lima PP, Vieira S, Meurer L, da Silveira TR, Matte U. Serum and tissue transforming [corrected] growth factor betal in children with biliary atresia. J Pediatr Surg. 2010;45:1784-90.

4. Du JX, Sun MY, Du GL, Li FH, Liu C, Mu YP, Chen GF, Long AH, Bian YQ, Liu J, Liu CH, Hu YY, Xu LM, Liu P. Ingredients of Huangqi decoction slow biliary fibrosis progression by inhibiting the activation of the transforming growth factor-beta signaling pathway. BMC Complement Altern Med. 2012;12:33.

5. Friedman SL. Hepatic fibrosis - overview. Toxicology. 2008;254:120-9.

6. Goldani HA, Matte US, Ramos AR, Costa TG, Winkelmann LV, Meurer L, Vieira SM, Kieling CO, Silveira TR. The role of food restriction on CCl4-induced cirrhosis model in rats. Exp Toxicol Pathol. 2007;58:331-7.

7. Inagaki Y, Okazaki I. Emerging insights into transforming growth factor beta Smad signal in hepatic fibrogenesis. Gut. 2007;56(2):284-92.

8. Kanzler S, Baumann M, Schirmacher P, Dries V, Bayer E, Gerken G, Dienes HP, Lohse AW. Prediction of progressive liver fibrosis in hepatitis $\mathrm{C}$ infection by serum and tissue levels of transforming growth factor-beta. J Viral Hepat 2001;8:430-7
9. Mizuguchi Y, Yokomuro S, Mishima T, Arima Y, Shimizu T, Kawahigashi Y, Kanda T, Yoshida H, Takizawa T, Tajiri T. Short hairpin RNA modulates transforming growth factor beta signaling in life-threatening liver failure in mice. Gastroenterology. 2005;129:1654-62.

10. Mukherjee S, Sorrell M. Noninvasive tests for liver fibrosis. Semin Liver Dis 2006;26:337-347.

11. Nakatsukasa H, Nagy P, Evarts RP, Hsia CC, Marsden E, Thorgeirsson SS Cellular distribution of transforming growth factor-beta 1 and procollagen types I, III, and IV transcripts in carbon tetrachloride-induced rat liver fibrosis. J Clin Invest. 1990;85:1833-43.

12. Neves LB, Catarino RM, Silva MR, Parise ER. [Increased serum levels of laminin in the experimental cirrhosis induced by carbon tetrachloride]. Arq Gastroenterol. 2003;40:173-6.

13. Parise ER, Oliveira AC, Figueiredo-Mendes C, Lanzoni V, Martins J, Nader H, Ferraz ML, Noninvasive serum markers in the diagnosis of structural liver damage in chronic hepatitis C virus infection. Liver Int. 2006;26:1095-9.

14. Pinzani M. Foreword to liver fibrosis. Best Pract Res Clin Gastroenterol. 2011;25:193-4

15. Rosa H, Parise ER. Is there a place for serum laminin determination in patients with liver disease and cancer? World J Gastroenterol. 2008;14:3628-3632.

16. Santos VN, Leite-Mór MM, Kondo M, Martins JR, Nader H, Lanzoni VP, Parise ER. Serum laminin, type IV collagen and hyaluronan as fibrosis markers in non-alcoholic fatty liver disease. Braz J Med Biol Res. 2005;38:747-53.

Received 21/12/2011 Accepted 15/6/2012. 